\title{
IDENTIFIKASI STRUKTUR BANGUNAN RUMAH TRADISIONAL DI DESA PINGGIRPAPAS
}

\author{
Anisah Nur Fajarwati ${ }^{1{ }^{1},}$, Medi Efendi ${ }^{2}$, Suhariyanto ${ }^{3}$, Sudarmanto ${ }^{4}$ \\ 1,2,3,4 Jurusan Teknik Sipil, Politeknik Negeri Malang, Jalan Soekarno Hatta No. 09 Malang, 65141 \\ anisah.fajar@gmail.com
}

Diterima: 09-12-2019 Direview : 06-04-2020 Direvisi: 16-05-2020 Disetujui: 17-05- 2020

\begin{abstract}
ABSTRAK. Arsitektur tradisional di Desa Pinggirpapas memiliki karakter dan kekhasan tersendiri. Karakter yang kuat dapat dilihat dari bentuk bangunan rumah tradisional yang mengandung nilai filosofis. Bangunan rumah tinggal di Desa Pinggirpapas terdiri dari tiga massa bangunan yang terikat dalam tanean atau halaman. Penelitian dengan judul Identifikasi Struktur Rumah Tinggal Tradisional di Desa Pinggirpapas, Kabupaten Sumenep bertujuan untuk mengenal bagian-bagian struktural konstruksi bangunan rumah tinggal tradisional yang masih menunjukkan jejak keaslian. Metode yang digunakan dalam penelitian ini adalah metode rasional-kualitatif yang bersifat deskriptif dan eksploratif, serta dalam pemilihan sampel bangunan digunakan metode purposive sampling. Analisis data dilakukan berdasarkan pembagian struktur bangunan yang terdiri dari struktur bawah, tengah, dan atas. Hasil penelitian menunjukkan bahwa rumah tradisional di Desa Pingirpapas memiliki keragaman struktur mulai dari struktur pandemen (pondasi), struktur tana' (lantai), struktur canggha dan sasaka ageng (kolom), dan struktur ata' (atap). Struktur bangunan rumah tradisional dibuat dengan sistem bongkar - pasang sehingga dapat dipindahkan dari satu tempat ke tempat yang lain. Ketiga massa bangunan menggunakan perpaduan material alam. Kayu jati untuk keseluruhan rangka bangunan (badan bangunan dan rangka atap). Batu karang untuk kaki bangunan atau pondasi, dan genteng tanah liat dari Palembang untuk penutup atap.
\end{abstract}

Kata kunci: Struktur, Rumah Tradisional, Desa Pinggirpapas

ABSTRACT. Traditional architecture in the village of Pinggirpapas has its character and uniqueness. A strong character can be seen in the form of traditional house buildings that contain philosophical values. Residential buildings in the village of Pinggirpapas consist of three building masses bound in a Tanean or courtyard. Research with the title Identification of Traditional Residential Structures in Pinggirpapas Village, Sumenep Regency aims to recognize the structural parts of traditional residential building construction that still show traces of authenticity. The study uses descriptive rationalqualitative methods that are descriptive and exploratory, and in the selection of building samples, the purposive sampling method is used. The parameter used as a reference in this study is the suitability of secondary data (theory) with the building's empirical conditions. Data analysis was performed based on the division of building structures consisting of the lower, middle, and upper structures. The results showed that traditional houses in Pingirpapas village had a variety of structures ranging from Pandemen (foundations), tana' structures (floors), Canggha structures and Sasaka Ageng (columns), and structures to Ata (roofs). The construction of a traditional house building is made with a knockdown system to move from one place to another. The three-building masses use a combination of natural materials. Teak wood for the overall frame of the building (building and roof frame). A chunk of coral reefs for building footings and clay tile from Palembang for roofing.

Keywords: Structure, Traditional House, Pinggirpapas Village

\section{PENDAHULUAN}

Desa Pinggirpapas terletak di Kecamatan Kalianget, Kabupaten Sumenep, Pulau Madura. Desa Pinggirpapas dikenal sebagai daerah yang memegang teguh adat istiadat. Salah satu acara adat yang rutin dilaksanakan setiap tahun adalah upacara Nyadhar, yaitu kegiatan bersama yang dilaksanakan sebagai wujud syukur atas melimpahnya garam dan juga sebagai bentuk penghargaan kepada leluhur.

Wujud asli bangunan rumah tinggal di Desa Pinggirpapas adalah berupa komplek bangunan yang terdiri dari tiga massa bangunan yaitu pandhepa, roma, dan dapor. Bangunan roma adalah bangunan yang berfungsi sebagai tempat tinggal, bangunan pandhepa berfungsi sebagai tempat untuk menerima tamu, dan bangunan dapor berfungsi sebagai tempat untuk menyiapkan 
makanan. Ketiga bangunan tersebut merupakan satu-kesatuan yang tersusun rapi

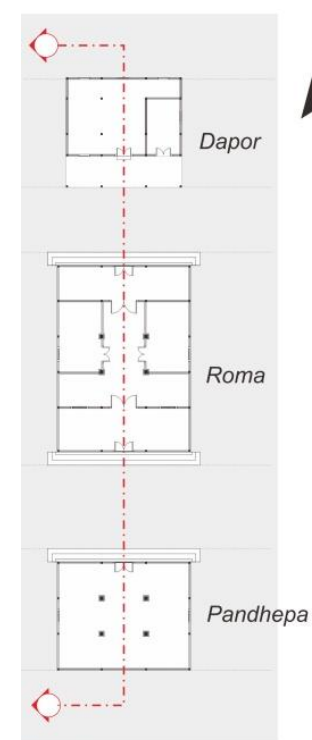

SITE PLAN

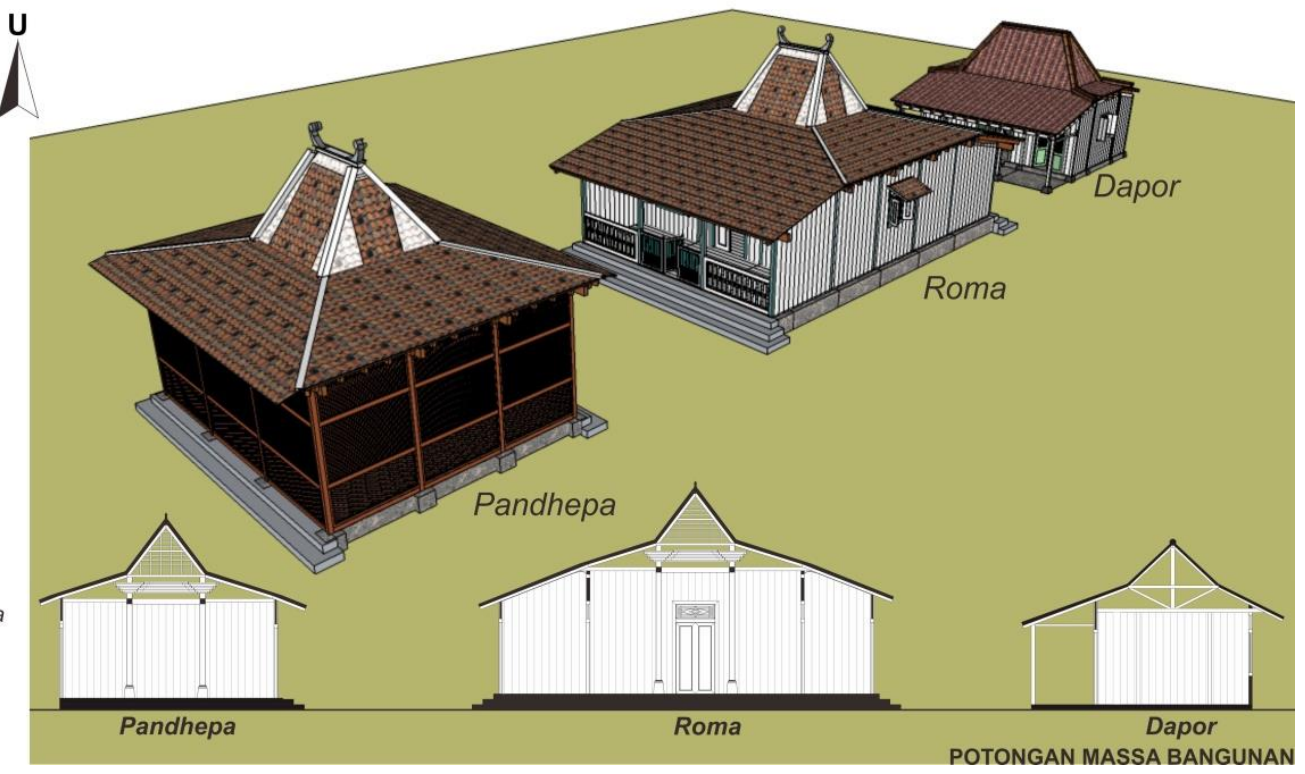

Gambar 1.Susunan rumah tradisional Desa Pinggirpapas (Sumber: Peneliti, 2019)
Ketiga massa bangunan memiliki struktur yang khas. Bangunan roma dan pandhepa memiliki kemiripan bentuk dasar dan struktur bangunan dengan bangunan Joglo Jawa. Struktur bangunan dapor lebih sederhana jika dibandingkan dengan bangunan roma dan pandhepa. Keseluruhan bagian struktur bangunan merupakan satu kesatuan yang tidak bisa dipisahkan.

Rumah petani garam di Desa Pinggirpapas saat ini telah mengalami penurunan baik dari segi kuantitas maupun kualitas. Arsitektur bangunan rumah tradisional di Desa Pinggirpapas ada yang masih menunjukan keasliannya, namun hampir seluruh bangunan yang tersisa sudah mengalami perubahan. Penurunan kualitas bangunan tersebut terkait dengan banyaknya permasalahan di dalam kawasan. Perlu dilakukan penelitian tentang identifikasi dan analisis struktur bangunan rumah tradisional untuk menjaga kelestariannya.

\section{METODE PENELITIAN}

Penelitian ini menggunakan metode rasionalkualitatif yang bersifat deskriptif dan eksploratif. Dalam pemilihan sampel bangunan digunakan metode purposive sampling. Variabel yang digunakan dalam penelitian ini antara lain adalah elemen struktur bangunan. Elemen struktur bangunan yang diteliti dibagi berdasarkan tiga segmentasi. Pembagian tersebut terdiri dari bagian bawah, tengah dan atas. Struktur bangunan dapat dilihat dari wujud fisik baik di bagian eksterior maupun interior bangunan.Lokasi penelitian berada di Desa Pinggirpapas Kecamatan Kalianget Kabupaten Sumenep Madura, Jawa Timur.

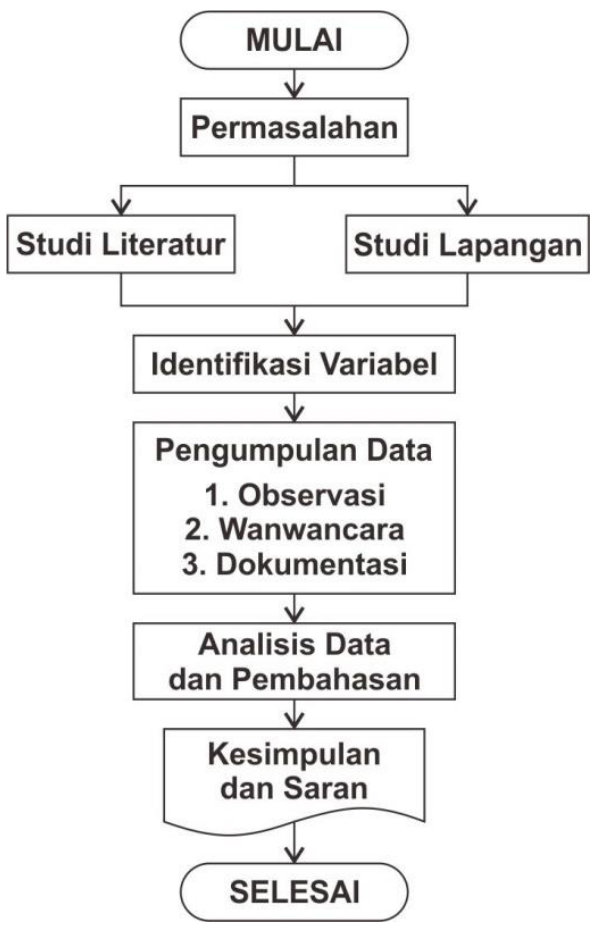

Gambar 2. Diagram Alir Penelitian.

(Sumber: Peneliti, 2019) 


\section{HASIL DAN PEMBAHASAN}

Bangunan rumah tradisional di Desa Pinggirpapas dibuat secara bongkar-pasang, sehingga memudahkan jika suatu saat pemilik rumah ingin memindahkannya ke lahan yang baru. Bangunan didirikan di suatu lahan kosong yang cukup luas dan dilengkapi dengan dua bangunan penunjang. Mukhtar et al., (2013) dalam penelitian tentang struktur dan konstruksi arsitektur tradisional, menjelaskan tentang kategori hubungan mendasar dari struktur spasial permukiman tradisional yang terdiri dari global space dengan element space dan hubungan antara element space itu sendiri. Di dalam arsitektur rumah tradisional di Desa Pinggirpapas, ketiga massa bangunan diikat menjadi satu-kesatuan di dalam tanean (halaman). Setiap bangunan memiliki fungsi masing-masing. Bangunan roma adalah bangunan yang memiliki fungsi paling penting (Gambar 3.). Bangunan roma adalah jiwa yang merupakan pusat segala aktivitas kehidupan penghuni.

Dalam pembahasan struktur rumah tinggal tradisional berkaitan erat anatomi bangunan (Mukhtar et al., 2013). Struktur rumah tradisional di Desa Pinggirpapas akan dibahas dalam tiga kategori berdasarkan anatomi bangunan, yaitu: struktur bagian bawah, struktur bagian tengah, dan struktur bagian atas.

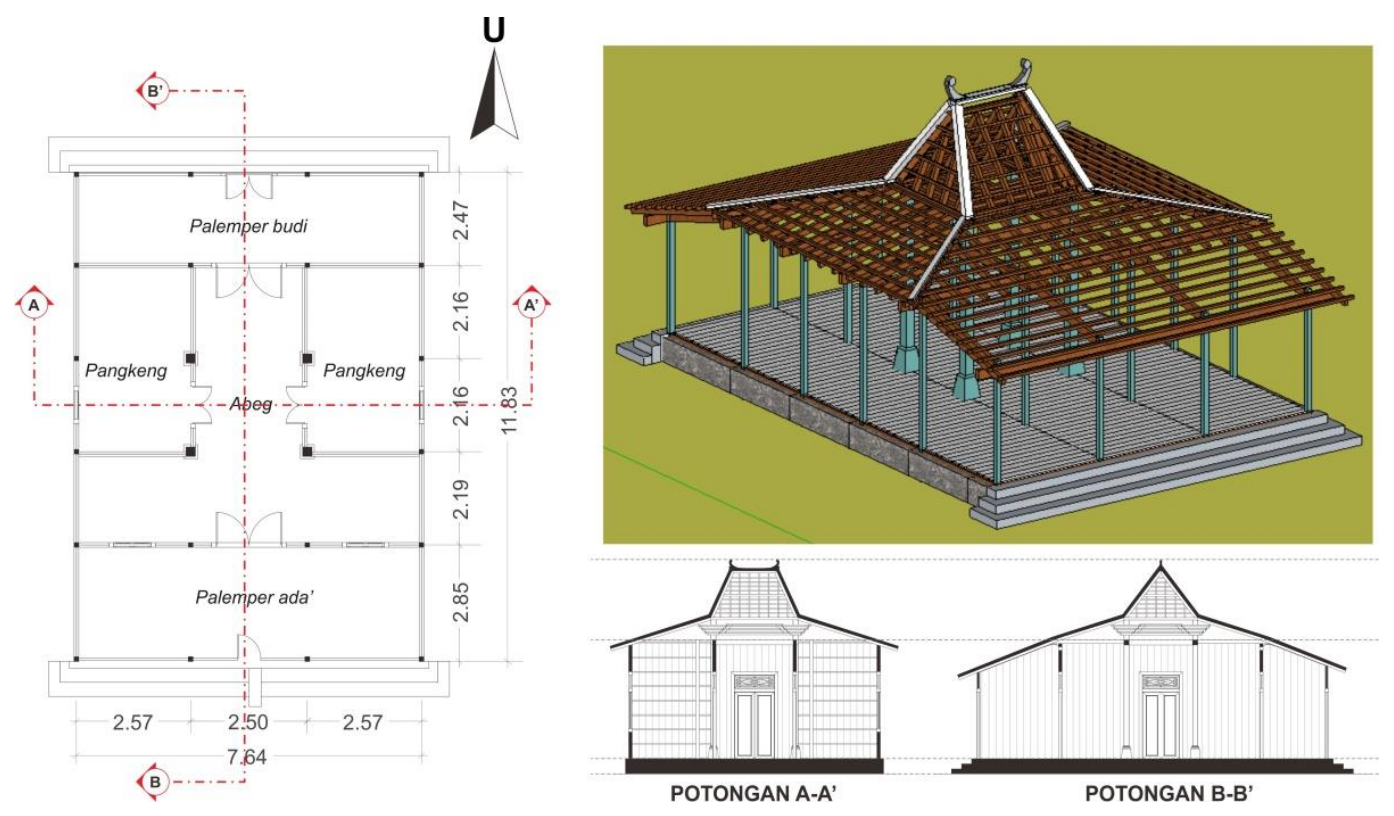

Gambar 3. Rangka Bangunan Roma

(Sumber: Analisis Peneliti, 2019)

\section{Struktur bagian bawah bangunan}

Struktur bagian bawah bangunan rumah tradisional di Desa Pinggirpapas adalah pondasi atau pandemen. Pondasi memiliki peranan untuk menerima dan menyalurkan beban lateral ke tanah. Pondasi terbuat dari material batu karang. Di bagian atas pondasi terdapat tarompa yang berfungsi untuk mengaitkan canggha atau kolom yang mengikat dinding dan juga lantai kayu (Gambar 4.). Canggha ditanam hingga kedalaman $25 \mathrm{~cm}$ di bawah pandemen. Material lantai atau tana' dalam istilah lokal menggunakan pelapis papan kayu jati di bangunan roma dan pandhepa. $\mathrm{Di}$ dapor material lantai yang digunakan adalah tanah. 


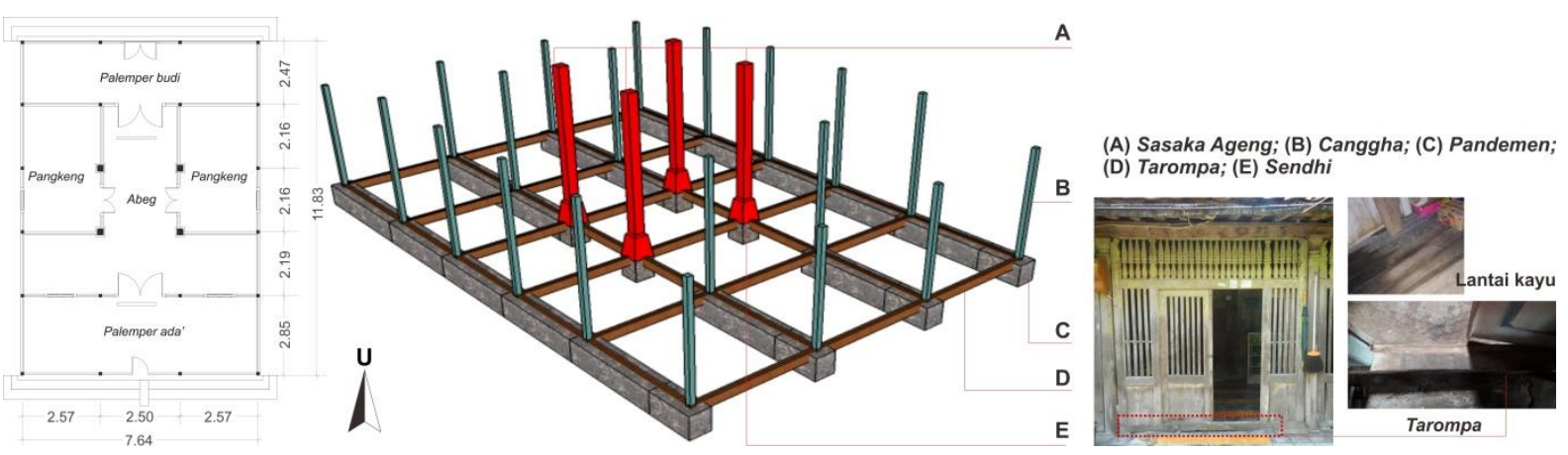

Gambar 4. Struktur dan konstruksi pondasi bangunan roma dan pandhepa (Sumber: Analisis Peneliti, 2019)

Sebelum pondasi, bagian yang pertama kali dibuat adalah sendhi. Jadi dari keselurahan bangunan, sendhi adalah bagian yang ditentukan pertama kali letaknya dan pertama kali pula dibuat. Sendhi terletak tidak di bawah lantai, melainkan di atas lantai dan menopang sasaka ageng (Gambar 5.).
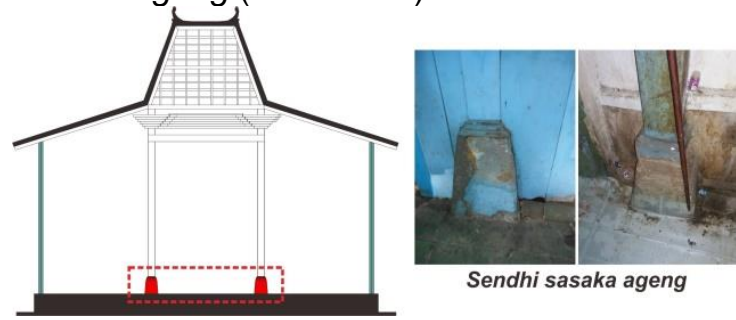

Gambar 5. Sendhi atau umpak sasaka ageng (Sumber: Analisis Peneliti, 2019)

Struktur bagian bawah lainnya adalah dhekondhek. Dhek-ondhek merupakan tangga masuk menuju ke dalam bangunan. Jumlah anak tangganya adalah ganjil satu atau tiga. Tidak ada struktur khusus dari dhek-ondhek (Gambar 6.). Dhek-ondhek hanya berupa potongan batu karang berukuran per level anak tangga $16 \mathrm{~cm}$ yang disusun di bagian depan dan belakang bangunan roma. Untuk bangunan pandhepa dan dapor, dhek-ondhek hanya ada di bagian depan.

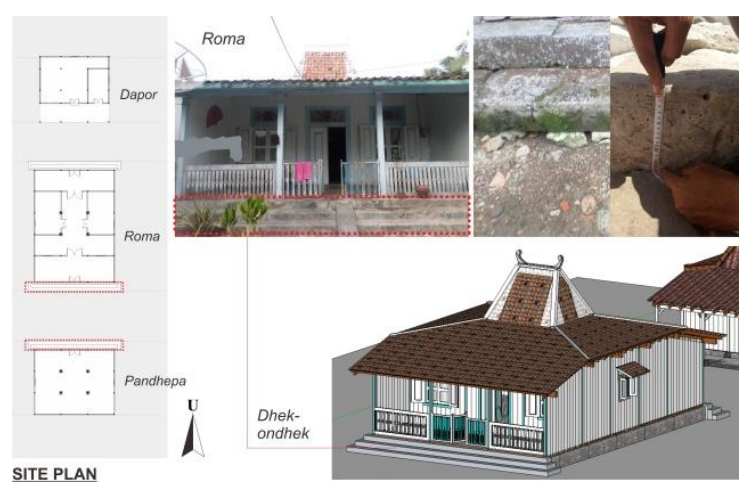

Gambar 6. Dhek-ondhek

(Sumber: Analisis Peneliti, 2019)

\section{Struktur bagian tengah bangunan}

Elemen struktur yang terdapat di bagian tengah bangunan terdiri dari canggha (tiang), tabing (dinding), pemasangan kusen pintu dan jendela, tabing (dinding), ge-ege (sambungan dinding), dan sasaka ageng. Hampir seluruh bagian tengah bangunan terbuat dari material kayu jati dan bisa dibongkar-pasang. Salah satu struktur dan konstruksi bagian tengah bangunan yang menjadi ciri khas dari bangunan rumah tradisional di Desa Pinggirpapas adalah racak (Gambar 7.). Racak adalah dinding pembatas yang memisahkan ruang-luar dengan ruang-dalam. Racak berupa kisi-kisi yang terbuat dari kayu yang disusun secara rapi dan dipasang dengan jarak $\pm 10 \mathrm{~cm}$. Racak tidak hanya terdapat di bangunan roma, tetapi juga terdapat di bangunan pandhepa. Potongan kayu yang digunakan untuk kisi-kisi dari racak berbentuk segitiga sama-sisi. Kisi-kisi dipasang dengan posisi salah satu sudut segitiga sama-sisi tersebut menghadap ke bagian luar bangunan.

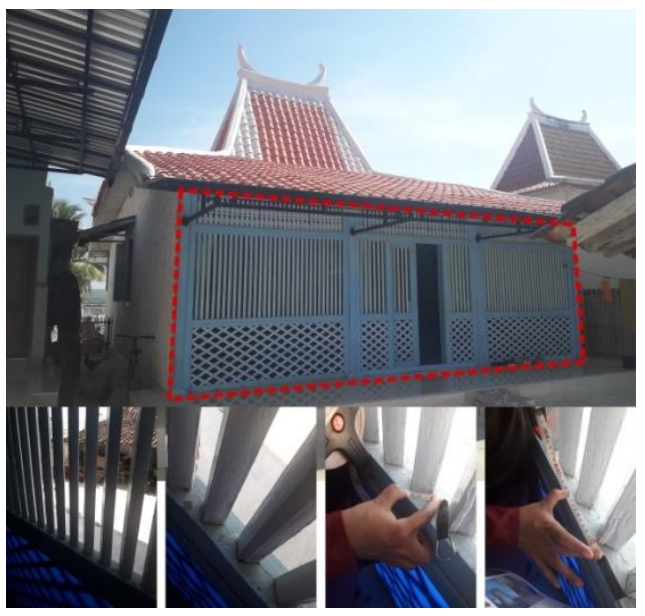

Gambar 7. Konstruksi racak (Sumber: Dokumentasi Peneliti, 2019)

Kolom atau canggha adalah bagian dari struktur tengah bangunan yang memiliki peran 
penting, yaitu sebagai pengikat dindingdinding. Struktur kolom atau canggha berdiri di atas tarompa dan turut menanggung beban dari struktur di bagian atasnya. Terdapat dua tipe canggha, yaitu yang terletak di bagian dalam bangunan dan canggha yang terletak di bagian palemper atau serambi di luar bangunan (Gambar 8.).

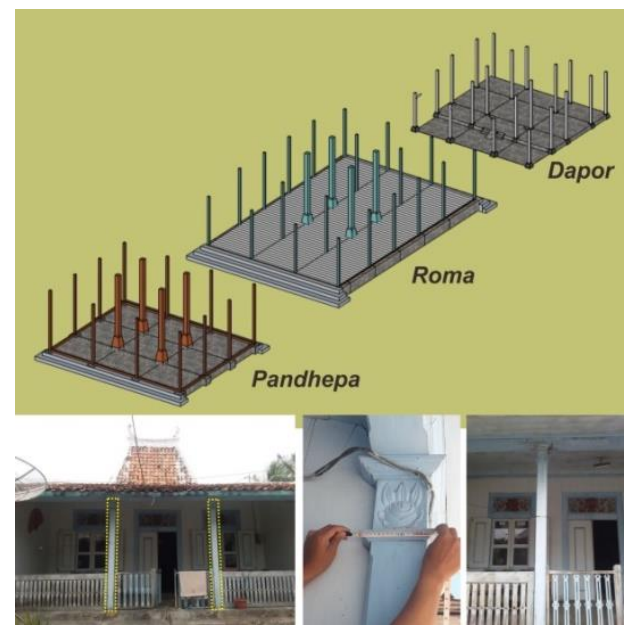

Gambar 8. Struktur dan konstruksi canggha (Sumber: Analisis Peneliti, 2019)

Changga yang terletak di bagian dalam bangunan memiliki ukuran penampang 10×10 $\mathrm{cm}$ dan tidak terlalu diekspos. Canggha yang terletak di bagian palemper atau serambi memiliki ukuran penampang $10 \times 10 \mathrm{~cm}$ dan berhiaskan ukiran menyerupai tanaman laut di bagian atasnya. Canggha di bagian serambi memiliki fungsi sebagai struktur penguat dan pengikat dari racak.

Bagian dari struktur tengah yang lain adalah dinding atau tabing (istilah masyarakat setempat). Tabing terbuat dari lembaran papan kayu jati yang memilik lebar $15-30 \mathrm{~cm}$, dengan panjang menyesuaikan tinggi dinding bangunan dan tebal sekitar $2 \mathrm{~cm}$. Terdapat pula ge-ege yang merupakan pengait atau pengikat antar papan kayu yang terletak di bagian ujung atau sudut pertemuan papan (Gambar 9.). Seperti halnya bangunan modern yang menggunakan dinding batu bata, pemasangan tabing atau dinding yang menjadi pembatas dengan bagian luar bangunan dipasang ganda atau double. Tabing di bagian dalam atau interior bangunan hanya dipasang selapis.

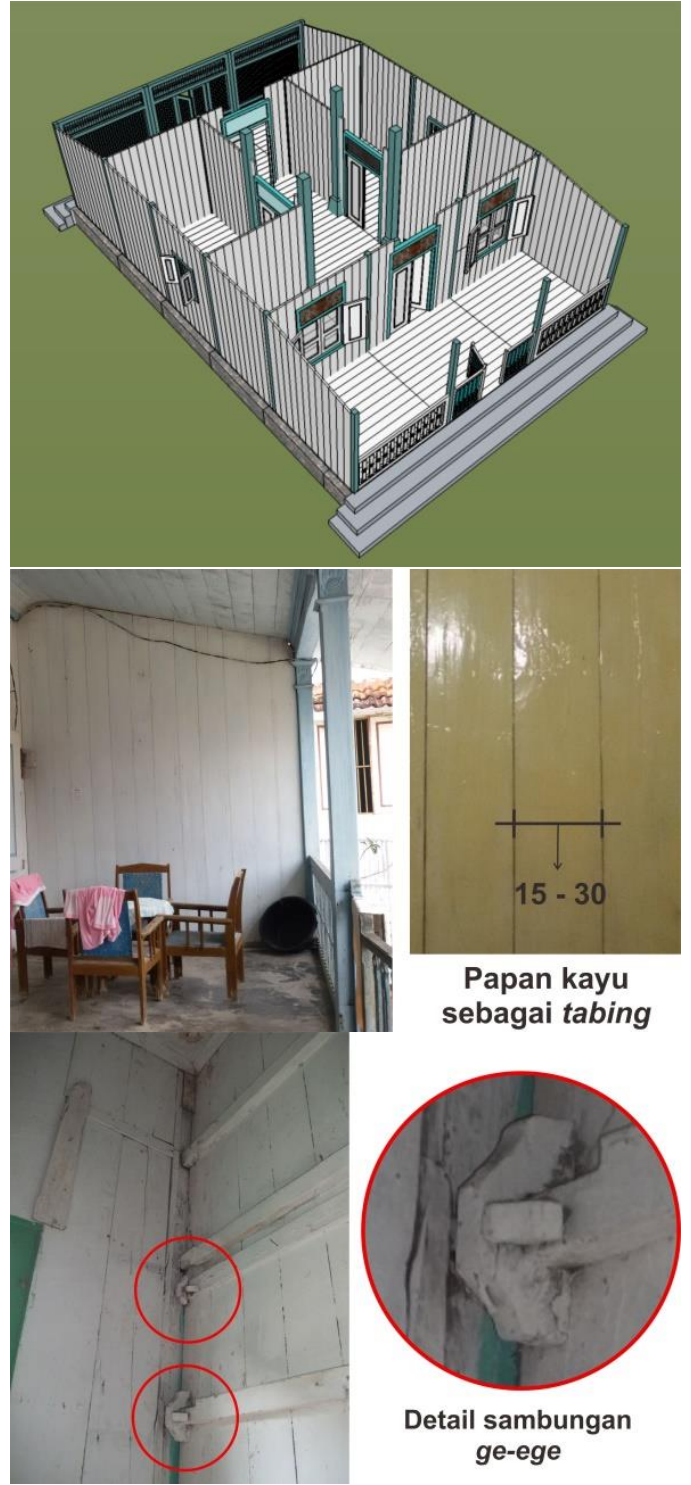

Gambar 9. Struktur dan konstruksi tabing (Sumber: Analisis Peneliti, 2019)

Struktur dan konstruksi lain yang melekat dengan tabing adalah kusen pintu dan jendela. Terdapat ring-jering atau angin-angin di bagian atas pintu maupun jendela.Pada umumnya di bangunan rumah tradisional (pandhepa, roma, dapur) menggunakan konstruksi pintu dan jendela ganda.Pintu di bagian racak pun juga menggunakan konstruksi pintu ganda dengan angin-angin di bagian atasnya. 


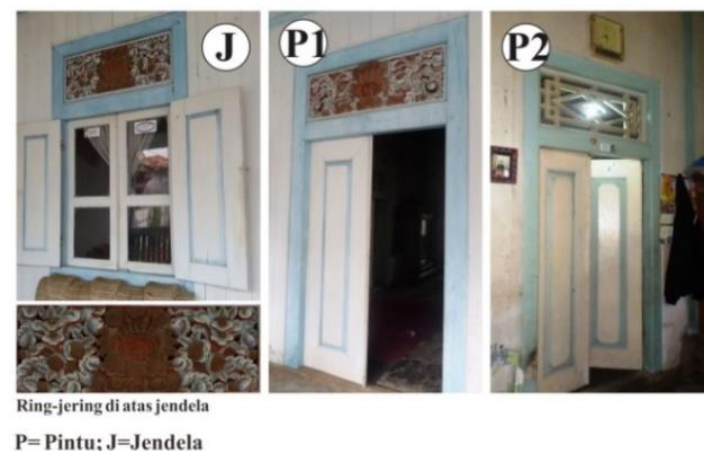

Gambar 10. Bentuk pintu dan jendela rumah tradisional di Desa Pinggirpapas (Sumber: Analisis Peneliti, 2019)

Di bagian luar bangunan, yaitu di bagian atas jendela digunakan sudha' atau tampias air hujan. Tampias ini terbuat dari kayu dan seng dipasang melekat dinding dengan konstruksi atap miring.

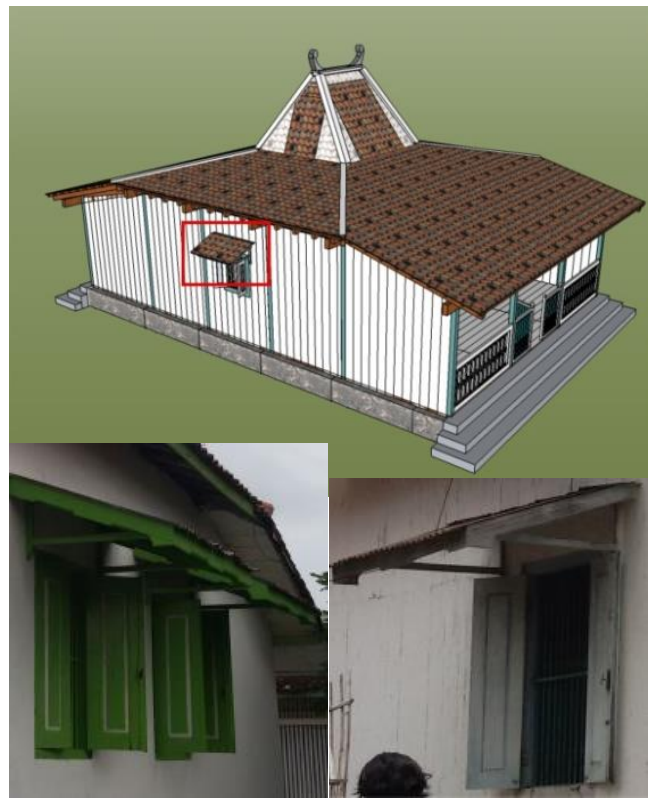

Gambar 11.Sudha' di bangunan roma (Sumber: Analisis Peneliti, 2019)

Bagian terpenting dari struktur bagian tengah dan juga menjadi ciri khas dari rumah tradisional di Desa Pinggirpapas selain racak adalah sasaka ageng (Gambar 12). Sasaka ageng merupakan struktur kolom utama yang terdapat di ketiga massa bangunan. Sasaka ageng terdiri dari empat kolom utama yang berukuran cukup besar yaitu sekitar 20x20 cm (sesuai besaran bangunan) dan terletak tepat di tengah-tengah bangunan atau yang biasa disebut dengan abeg.

Sasaka ageng adalah elemen struktural yang pertama kali dirangkai dan didirikan di dalam lahan. Hal ini memiliki kemiripan dengan rumah tradisional Jawa yang diteliti oleh
Sudarwanto \& Murtomo (2013), yaitu soko guru. Soko guru merupakan karakter dari rumah Pencu yang dirangkai terlebih dahulu untuk mengawali pembangunan rumah. Sasaka ageng dan soko guru terdiri dari dari empat tiang utama yang beridiri di atas umpak. Jajaran keempat tiang tersebut membentuk suatu dimensi ruang sebagai inti dari bangunan. Ruang inti tersbut adalah abeg dalam istilah lokal masyarakat Desa Pinggirpapas, dan disebut dengan istilah rongrongan untuk rumah Pencu Jawa. Secara struktural, soko guru dan juga sasaka ageng memiliki fungsi yang sama yaitu sebagai penerima beban dari struktur atap kemudian menyalurkannya ke bagian struktur bawah bangunan.

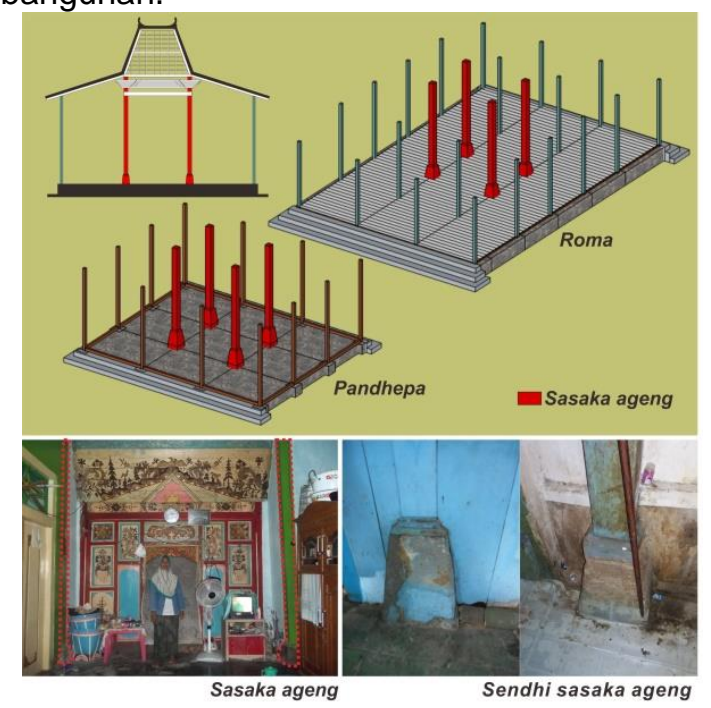

Gambar 12. Posisi sasaka ageng di dalam bangunan

(Sumber: Analisis Peneliti, 2019)

\section{Struktur bagian atas bangunan}

Bagian atas bangunan rumah tradisional adalah atap, atau yang biasa disebut dengan ata' oleh masyarakat setempat. Bangunan pandhepa dan roma memiliki struktur dan konstruksi atap yang hampir sama, yaitu menggunakan atap joglo yang terpotong di bagian samping (kiri dan kanan) atau yang dikenal dengan bentuk rumah atap bangsal. Untuk bangunan roma terdapat penambahan atap miring di bagian palemper ada' dan palemper budi (serambi). Berbeda dengan bangunan pandhepa dan bangunan roma, bangunan dapor menggunakan jenis atap limasan terpatah atau yang biasa disebut dsengan pegun. 


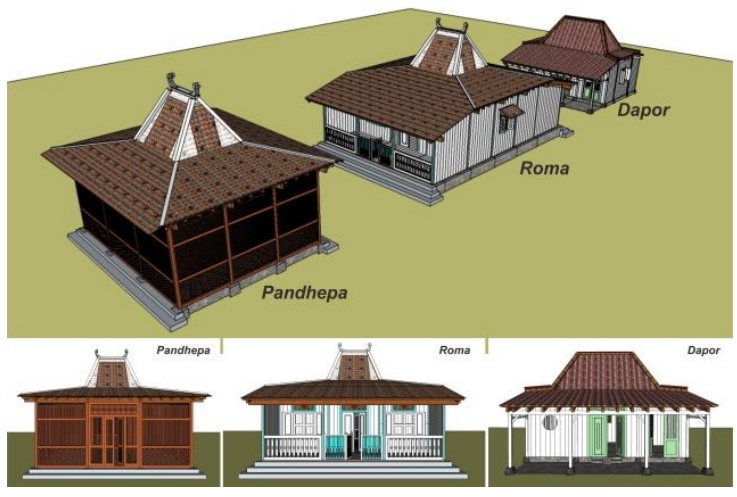

Gambar 13. Bentuk atap rumah tradisional di Desa Pinggirpapas

(Sumber: Analisis Peneliti, 2019)

Struktur atap yang digunakan adalah struktur atap kayu. Material kayu yang digunakan adalah kayu jati yang telah berumur lebih dari 100 tahun (sesuai dengan usia rumah). Untuk bagian penutup atap menggunakan genteng tanah liat dengan tambahan ornamen kondhi di bagian puncak atap bangunan pandhepa dan roma. Secara umum bagian atap bangunan terdiri dari: kondhi, bubung (bubungan), genteng, reng-ereng (reng), osok (usuk), dan patampa (gording) (Gambar 14.). Untuk bangunan pandhepa dan roma terdapat tambahan bagian atap, yaitu totop sendhi, sondhu', dan tompangsare. Ada pula kanopi atau sun shading yang biasa disebut dengan sudha'. Keseluruhan kerangka atap dirangkai menggunakan pasak yang terbuat dari kayu. Bagian struktur atas bangunan yang menjadi

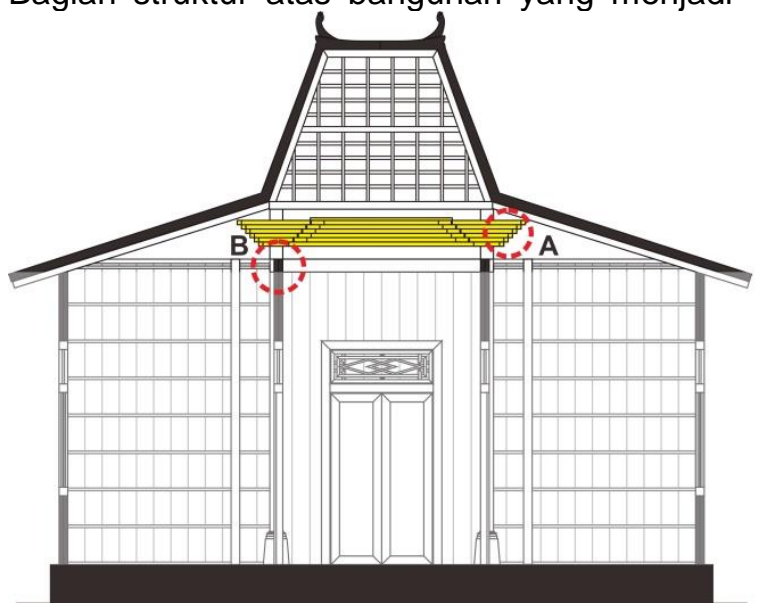

Gambar 15. Detail Sambungan atap

(Sumber: Analisis Peneliti, 2019) ciri khas dari bangunan rumah tradisional di Desa Pinggirpapas adalah adanya ornamen kondhi dan tompangsare. Ornamen kondhi adalah ornamen yang umum digunakan di bagian atap rumah trasional di Sumenep dan di Desa Pinggirpapas khususnya.

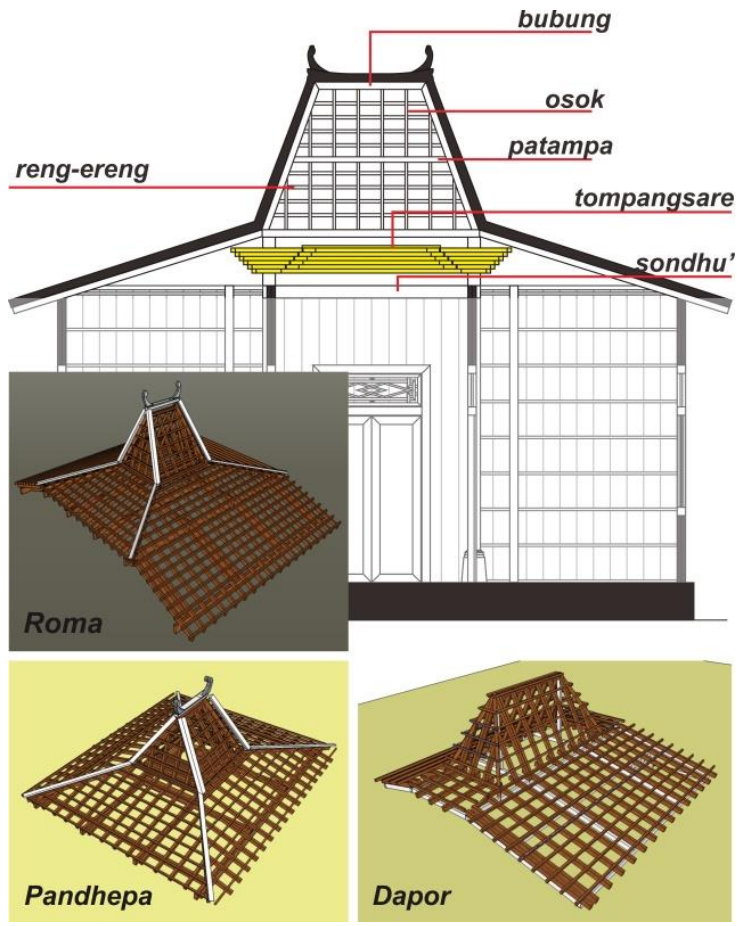

Gambar 14. Elemen Struktural Rangka Atap (Sumber: Analisis Peneliti, 2019)

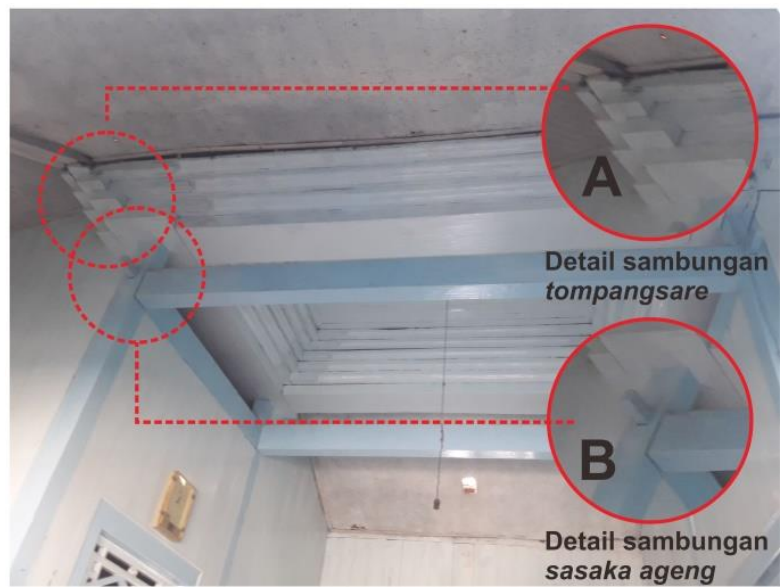
Detail sambungar
sasaka ageng

berundak seperti tingkatan dalam piramida maya (Gambar 16.). Selain menjadi karakter dari bangunan pandhepa dan roma, jumlah tingkatan tompangsare menggambarkan strata penghuni rumah. Semakin banyak jumlah tingkatannya, semakin tinggi pula kedudukannya dalam masyarakat. Jumlah
Menurut Fajarwati (2015) selain kondhi, tompangsare adalah bagian yang menjadi ciri khas dari rumah tradisional di Desa Pinggirpapas. Tompangsare adalah bagian dari struktur ata' atau atap bangunan yang terletak tepat di atas sondhuk' yang disangga oleh sasaka ageng. Bentuk dari tompangsare 
tingkatan tompangsare adalah ganjil, dan yang terbanyak adalah 9 tingkatan. Tompangsare dengan tingkatan terbanyak ini terdapat rumah peninggalan leluhur, atau yang biasa disebut dengan pasarean juju'. Jumlah lainnya adalah satu, tiga, lima dan tujuh.

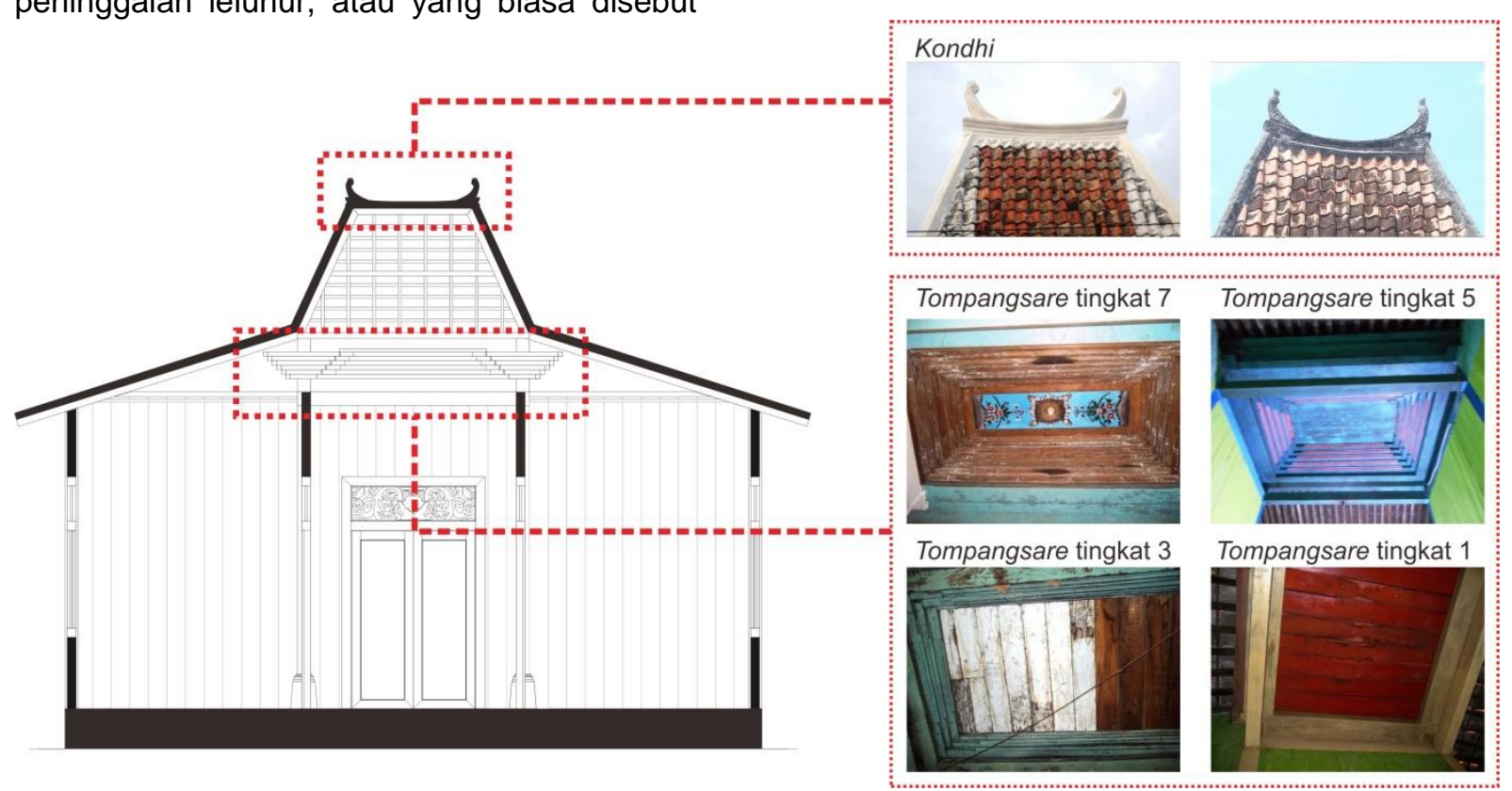

Gambar 16.Kondhi dan tompangsare di bagian atap rumah tradisional di Desa Pinggirpapas

(Sumber: Analisis Peneliti, 2019)

Secara keseluruhan rangka kayu di bangunan rumah tradisional di Desa Pinggirpapas dibuat tidak permanen. Artinya, bagian-bagian rangka kayu ini bisa dibongkar dan dipindahkan untuk dirangkai kembali di tapak yang lain atau tapak baru. Struktur bagian atas bangunan rumah tradisional di Desa Pinggirpapas menjadi karakter terkuat dari fasade atau tampak bangunan, dibandingkan dengan bagian

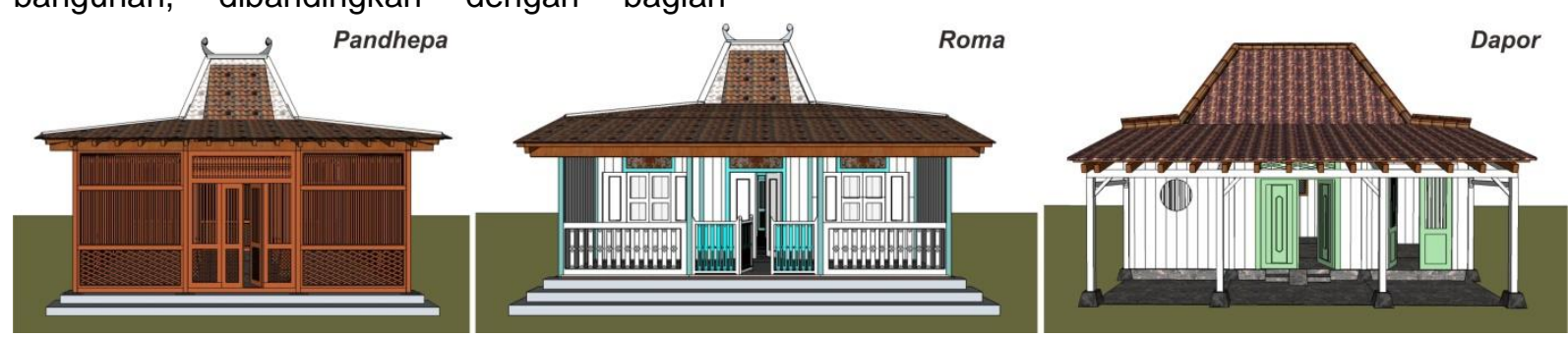

Gambar 17. Komposisi fasade atau tampak bangunan rumah tradisional di Desa Pinggirpapas

(Sumber: Analisis Peneliti, 2019)

Tabel 1. Matrikulasi Struktur Bangunan Tradisional di Desa Pinggirpapas

\begin{tabular}{|c|c|c|c|c|c|c|}
\hline \multirow[b]{2}{*}{ No. } & \multicolumn{2}{|r|}{ Struktur Bangunan } & \multirow[b]{2}{*}{ Material } & \multicolumn{3}{|c|}{ Massa Bangunan } \\
\hline & $\begin{array}{l}\text { Pembagian } \\
\text { Struktur }\end{array}$ & Elemen Struktur & & Pandhepa & Roma & Dapor \\
\hline \multirow[t]{5}{*}{1.} & $\begin{array}{l}\text { Struktur } \\
\text { bawah }\end{array}$ & $\begin{array}{l}\text { Pandemen } \\
\text { (pondasi) }\end{array}$ & Batu karang & $\sqrt{ }$ & $\sqrt{ }$ & $\sqrt{ }$ \\
\hline & & Tarompa & Kayu jati & $\sqrt{ }$ & $\sqrt{ }$ & $\sqrt{ }$ \\
\hline & & Dhek-ondhek (tangga) & Batu karang & $\sqrt{ }$ & $\sqrt{ }$ & \\
\hline & & Tana' (lantai) & Kayu, tanah & $\sqrt{ }$ & $\sqrt{ }$ & $\sqrt{ }$ \\
\hline & & Sendhi (umpak) & Kayu jati & $\sqrt{ }$ & $\sqrt{ }$ & $\sqrt{ }$ \\
\hline \multirow[t]{2}{*}{2.} & Struktur & Canggha (kolom) & Kayu jati & $\sqrt{ }$ & $\sqrt{ }$ & $\sqrt{ }$ \\
\hline & tengah & $\begin{array}{l}\text { Sasaka ageng (empat kolom besar } \\
\text { utama) }\end{array}$ & Kayu jati & $\sqrt{ }$ & $\sqrt{ }$ & $\sqrt{ }$ \\
\hline
\end{tabular}




\begin{tabular}{llllll}
\hline & Tabing (dinding kayu) & Kayu jati & $\sqrt{ }$ & $\sqrt{ }$ & $\sqrt{ }$ \\
\cline { 2 - 6 } & Racak & Kayu jati & $\sqrt{ }$ & $\sqrt{ }$ & - \\
\cline { 2 - 6 } & Ge-ege (sambungan dinding) & Kayu jati & $\sqrt{ }$ & $\sqrt{ }$ & $\sqrt{ }$ \\
\hline \multirow{2}{*}{ 3. Struktur atas } & Sondhu' & Kayu jati & $\sqrt{ }$ & $\sqrt{ }$ & $\sqrt{ }$ \\
\cline { 2 - 6 } & Tompangsare & Kayu jati & $\sqrt{ }$ & $\sqrt{ }$ & - \\
\cline { 2 - 6 } & Totop sendhi & Kayu jati & $\sqrt{ }$ & $\sqrt{ }$ & - \\
\cline { 2 - 6 } & Reng-ereng (reng) & Kayu jati & $\sqrt{ }$ & $\sqrt{ }$ & $\sqrt{ }$ \\
\cline { 2 - 6 } & Osok (usuk) & Kayu jati & $\sqrt{ }$ & $\sqrt{ }$ & $\sqrt{ }$ \\
\cline { 2 - 6 } & Patampa (gording) & Kayu jati & $\sqrt{ }$ & $\sqrt{ }$ & $\sqrt{ }$ \\
\cline { 2 - 6 } & Bubung (bubungan) & Kayu jati & $\sqrt{ }$ & $\sqrt{ }$ & $\sqrt{ }$ \\
\cline { 2 - 6 } & Kondhi & Tanah & $\sqrt{ }$ & $\sqrt{ }$ & - \\
\hline
\end{tabular}

Sumber: Analisis Peneliti, 2019

\section{KESIMPULAN}

Struktur rumah tradisional di Desa Pinggirpapas terdiri dari tiga massa bangunan yaitu bangunan roma, pandhepa, dan dapor. Struktur dan konstruksi bangunan rumah tinggal tradisional dapat diuraikan sebagai berikut:

a. Struktur bangunan rumah tradisional dibuat dengan sistem bongkar-pasang sehingga dapat dipindahkan dari satu tempat ke tempat yang lain.

b. Elemen struktural yang paling dominan terletak di bagain atas bangunan yaitu atap. Jenis atap yang digunakan adalah atap bangsal untuk bangunan roma dan pandhepa. Jenis atap yang digunakan untuk banguan dapor adalah jenis atap pegun.

c. Secara keseluruhan, sistem struktur dirangkai dengan sistem sambungan.

d. Sistem struktur menciptakan bentuk ruang simetri dengan sasaka ageng sebagai inti dari struktur bangunan.

e. Struktur bagian bawah dari ketiga massa bangunan (roma, pandhepa, dan dapor) menggunakan pandemen atau pondasi yang ditanam di dalam tanah. Pondasi ini menjadi penopang utama rangka atap bangunan.

f. Struktur bagian tengah bangunan terdiri dari tabing (dinding), canggha (kolom praktis) yang terikat dengan tarompa, dan sasaka ageng (kolom struktur utama).

g. Struktur bagian atas bangunan (struktur dan konstruksi atap) menggunakan tipe atap bangsal dan pegun yang terdiri dari sondhuk, totop sendhi, patampa, osok, dan reng-ereng.

Rumah tradisional di Desa Pingirpapas menggunakan perpaduan material alam. Kayu jati untuk keseluruhan rangka bangunan (badan bangunan dan rangka atap). Batu karang untuk kaki bangunan atau pondasi. Genteng tanah liat dari Palembang untuk penutup atap.
Hasil penelitian memberikan rekomendasi penelitian lanjutan tentang:

a. Pelestarian bangunan tradisional.

b. Pengembangan Desa Wisata.

c. Modernisasi yang menyebabkan terjadinya perubahan bangunan rumah tinggal tradisional.

\section{UCAPAN TERIMA KASIH}

Terima kasih disampaikan kepada Politeknik Negeri Malang yang telah mendanaikeberlangsungan penelitian ini dalam Dana Penelitian DIPA Reguler Politeknik Negeri Malang.

\section{DAFTAR PUSTAKA}

Fajarwati, A. N. (2015). Arsitektur Rumah Tradisional Di Desa Plnggirpapas Kecamatan Kalianget Kabupaten Sumenep Madura. Universitas Gadjah Mada.

Mukhtar, M. A. ... Wulandari, L. D. (2013). Struktur Konstruksi Arsitektur Tradisional Bangunan Tradisional Keda Suku Ende Lio Di Permukiman Adat Wolotolo. Review of Urbanism and Architectural Studies, 11(1), 16-27. https://doi.org/10.21776/ub.ruas.2013.01 1.01 .2

Sudarwanto, B., \& Murtomo, A. (2013). Studi Struktur dan Konstruksi Bangunan Tradisional Rumah 'Pencu' di Kudus. Ikatan Peneliti Lingkungan Binaan Indonesia Studi, 2(1), 35-42. 
